\title{
Dynamic influences of nutrients and grazing fish on periphyton during recovery from flood
}

Author(s) :Justin N. Murdock, Walter K. Dodds, Keith B. Gido, and Matt R. Whiles

Source: Journal of the North American Benthological Society, 30(2):331-345. 2011.

Published By: North American Benthological Society

DOI: $10.1899 / 10-039.1$

URL: http://www.bioone.org/doi/full/10.1899/10-039.1

BioOne (www.bioone.org) is a nonprofit, online aggregation of core research in the biological, ecological, and environmental sciences. BioOne provides a sustainable online platform for over 170 journals and books published by nonprofit societies, associations, museums, institutions, and presses.

Your use of this PDF, the BioOne Web site, and all posted and associated content indicates your acceptance of BioOne's Terms of Use, available at www.bioone.org/page/terms_of_use.

Usage of BioOne content is strictly limited to personal, educational, and non-commercial use. Commercial inquiries or rights and permissions requests should be directed to the individual publisher as copyright holder. 


\title{
Dynamic influences of nutrients and grazing fish on periphyton during recovery from flood
}

\author{
Justin N. Murdock ${ }^{1}$, Walter K. Dodds ${ }^{2}$, AND Keith B. Gido ${ }^{3}$ \\ Division of Biology, Kansas State University, Manhattan, Kansas 66506 USA \\ Matt R. Whiles ${ }^{4}$ \\ Department of Zoology and Center for Ecology, Southern Illinois University, Carbondale, \\ Illinois 62901 USA
}

\begin{abstract}
Nutrients and grazers both can regulate benthic algal structure and function in streams, but the relative strength of each factor depends on stream biotic and abiotic conditions. The abundance of stream organisms and nutrient availability can change rapidly after a flood. Thus, nutrient and grazer influences on algal development and how these drivers interact may vary temporally during recovery. We measured benthic structural and functional development for $35 \mathrm{~d}$ after a simulated flood in large outdoor mesocosms under a gradient of 6 nutrient loadings crossed with 6 densities of grazing fish (Southern redbelly dace, Phoxinus erythrogaster). Nutrients influenced algal development more than dace did and were better correlated with algal function (area-specific primary productivity and nutrient uptake) than with structure (biomass). Dace influenced all structural variables and biomass-specific gross primary productivity, but their influence was relatively weak and was observed only early in recovery. Dace influence weakened and nutrient influence strengthened during recovery. Understanding context-dependent relationships in postdisturbance community dynamics is essential for predicting ecosystem responses to future changes in nutrient inputs and biodiversity, particularly in systems, such as headwater streams, with frequent disturbance.
\end{abstract}

Key words: algae, benthic, bottom-up, disturbance, stream, top-down, mesocosm.

Benthic algal dynamics in streams can be regulated by either top-down (grazer) or bottom-up (nutrient) factors (Power et al. 1988a, Hillebrand 2002, Worm et al. 2002). Direct consumption or physical displacement of algae by grazers can have strong negative effects on benthic algal growth (Feminella and Hawkins 1995, Hillebrand 2002, Liess and Hillebrand 2004, Gruner et al. 2008). However, grazers and benthivores also can stimulate primary producer growth in a range of aquatic habitats, including tropical streams (Flecker et al. 2002, McIntyre et al. 2007), lakes and reservoirs (Gido 2002, McIntyre et al. 2008), wetlands (Zimmer et al. 2006), and coastal

\footnotetext{
${ }^{1}$ Present address: National Sedimentation Laboratory, Agricultural Research Service, US Department of Agriculture, Oxford, Mississippi 38655 USA. E-mail: justin.murdock@ars. usda.gov

2 wkdodds@k-state.edu

${ }^{3}$ kgido@k-state.edu

4 mwhiles@zoology.siu.edu
}

marine systems (Meyer et al. 1983). This stimulatory response is often linked to nutrient remineralization through grazer excretion (Vanni 2002, Hall et al. 2007), but also can occur via removal of algae with low productivity and displacement or decreased feeding efficiency of other consumers (Power 1990, McIntosh and Townsend 1996). Therefore, the net effect of grazers on algal biomass should reflect the balance between loss and stimulation. In nonequilibrium systems, such as streams, this balance is dynamic because grazing pressure and nutrient availability can change with time.

Grazer effects on algal growth vary depending on ecosystem conditions, such as grazer and algal diversity or algal accumulation rates (Flecker et al. 2002, Vanni et al. 2006, Gruner et al. 2008, Murdock et al. 2010). Hillebrand (2009) suggested that grazers are most efficient (i.e., remove the greatest proportion of algal biomass) when algal biomass is high, a condition more likely to occur in streams during late rather than early successional periods. In contrast, results of 
theoretical and empirical studies suggest that grazer stimulation of algae via nutrient remineralization will vary with community composition and nutrient availability and should be strongest when nutrients are limiting and grazer biomass is low to moderate (DeAngelis 1992, Flecker et al. 2002). Thus, the balance between grazer consumption and stimulation should change predictably along a gradient of nutrient loading.

Many streams are characterized by disturbances that repeatedly disrupt biotic and abiotic components (Poff and Ward 1989, Lake 2000). Following disturbances, such as floods, top-down and bottom-up regulators of algae can change rapidly (Resh et al. 1988, Dodds et al. 2004). Floods can reduce producer and consumer populations disproportionately because larger organisms, such as fish, can seek refuge in low-velocity habitats, whereas smaller, more sedentary algae and benthic invertebrates are scoured (Dodds et al. 1996, 2004). These disturbances may result in highly context-dependent effects of grazing fish on algae. Effects of grazer-nutrient interactions on algae are also likely to influence stream ecosystem function (i.e., primary productivity and nutrient retention). The speed and magnitude of changes in grazer and nutrient relationships with shifting environmental conditions in streams are not well understood because few grazer studies have been done outside stable flow regimes (Hillebrand 2002, but see Gelwick and Matthews 1992, Bertrand et al. 2009).

Prairie streams are particularly good systems for studying responses to disturbances in a nonequilibrium setting. After scouring floods, algal biomass typically accrues exponentially early in recovery and peaks within 2 to 4 wk (Dodds et al. 2002, Murdock and Dodds 2007). Macroinvertebrate diversity can reach preflood abundance within 3 to $4 \mathrm{wk}$ (Fritz and Dodds 2004), and fish communities often remain stable (Franssen et al. 2006). Differential colonization and growth rates create constantly shifting grazer: algae biomass ratios and can cause the net influence of grazers on algae to change quickly during recovery (Murdock et al. 2010).

We studied the influence of grazing minnows on algal structural and functional recovery from a simulated flood across a range of fish densities and nutrient levels. Our goal was to assess the relative effects and temporal variability of grazing fish and nutrient availability on periphyton recovery. Maintaining gradients of nutrients and grazer biomass across a series of riffles and pools while controlling other factors would be extraordinarily difficult in a natural stream. Therefore, we created experimental gradients of nutrients and grazing in a large array of outdoor stream mesocosms. We hypothesized that nutrients would be the major driver of algal recovery and predicted that the influence of fish would vary temporally with changing fish:algae biomass ratios (i.e., consumption efficiency) and algal accumulation rates (Gido et al. 2010).

\section{Methods}

\section{Experimental design}

Thirty-six large outdoor mesocosms at the Konza Prairie Biological Station in northeastern Kansas were used to test the interactive effect of nutrients and grazing fish (Southern redbelly dace, Phoxinus erythrogaster) on periphyton recovery. Each mesocosm consisted of a $2.5-\mathrm{m}^{2}$ pool connected to a $0.84-\mathrm{m}^{2}$ riffle (Fig. 1; see Matthews et al. 2006 for a description of the basic design of these mesocosms). Spring water was supplied continuously at $\sim 1000 \mathrm{~L} / \mathrm{d}$ to each mesocosm. Water was recirculated with an electric trolling motor to create a discharge of 4 to $6 \mathrm{~L} / \mathrm{s}$ and a mean current velocity of 6 to $8 \mathrm{~cm} / \mathrm{s}$ in the riffle. Spring-water nutrient concentrations were low (total $\mathrm{N}$ [TN]: $180 \mu \mathrm{g} / \mathrm{L}$, total P [TP]: $4 \mu \mathrm{g} / \mathrm{L}, \mathrm{NO}_{3}{ }^{-}-\mathrm{N}$ : $30 \mu \mathrm{g} / \mathrm{L}$, dissolved reactive $\mathrm{P}$ [DRP]: $1 \mu \mathrm{g} / \mathrm{L}$ ). A canopy reduced ambient sunlight by $60 \%$, and water temperature ranged from 18.6 to $23.7^{\circ} \mathrm{C}$ (mean = $21.1^{\circ} \mathrm{C}$ ). Substrata were a mixture of pebbles, gravel, and fine sediment derived from local limestone and shale and were similar in size and texture to substrata in nearby streams. Enough substrata volume was added to approximate the subsurface areas of nearby streams.

Mesocosms were filled on 20 April 2007, and a benthic slurry from nearby Kings Creek was added to all mesocosms to provide a source of potential microbial and invertebrate colonists typical of this stream. Aquatic insects emerging from Kings Creek also readily colonized mesocosms. After $30 \mathrm{~d}$, mesocosms were scoured with a high-pressure hose and drained to simulate flooding as described by Bertrand et al. (2009). Mesocosms were refilled with water and circulation was started within $24 \mathrm{~h}$. The simulated flooding reset the benthic algal and macroinvertebrate community by removing most of their biomass. Flooding created similar biological starting points among mesocosms (Bengtson et al. 2008, Bertrand et al. 2009) that were similar to postflood benthic communities in a nearby stream (Gido et al. 2010).

The focus of our study was the individual and combined effects of fish and nutrients on the recovery dynamics of stream algae. Therefore, sampling was done during the period from immediately after the disturbance to the peak in algal accumulation. In 


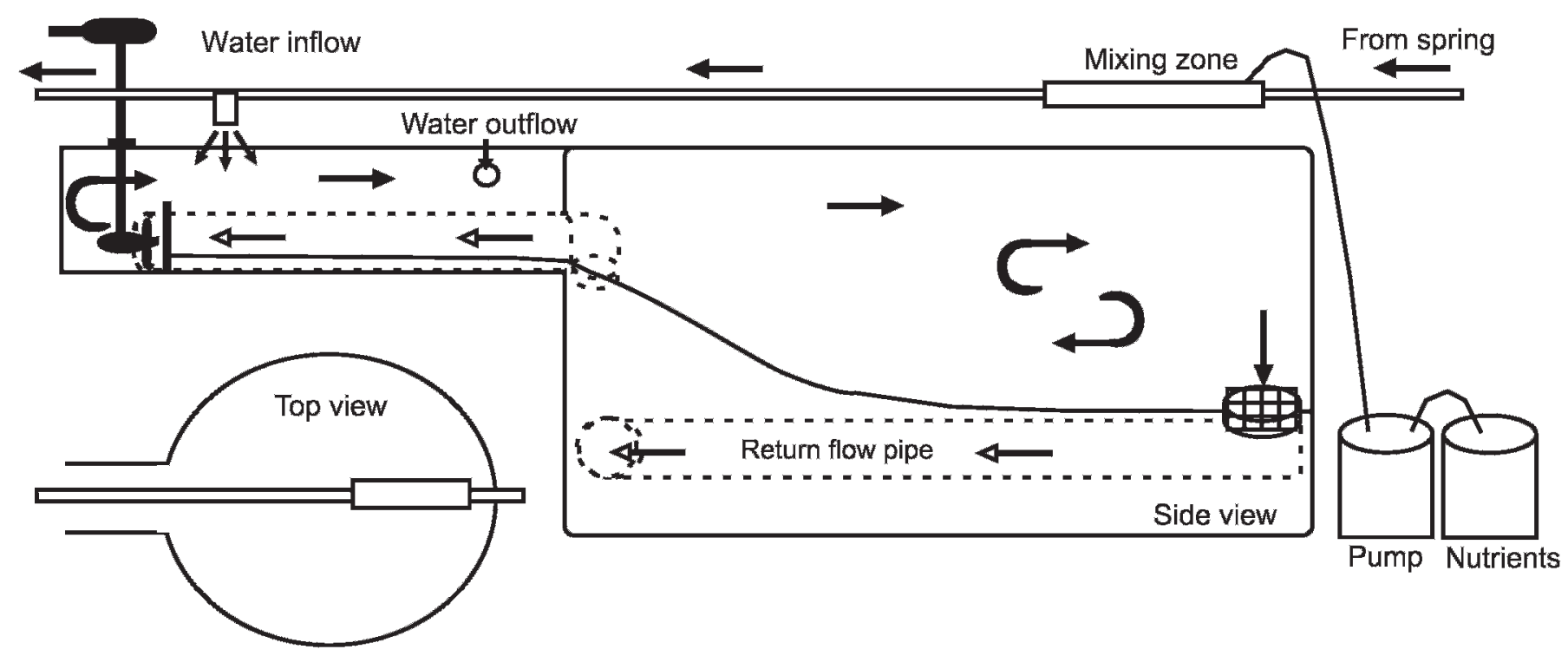

FIG. 1. Diagram of mesocosms and nutrient-addition apparatus. Each mesocosm ( $\sim 1800$ L) consisted of a riffle and pool section, and water was recirculated through buried tubing with a trolling motor. Arrows denote water movement into and through mesocosms. See text for details.

prairie streams, floods often scour and remove most of the benthic organic matter, but fish are more resistant because they can move laterally and avoid current. Therefore, fish additions directly following simulated floods simulated an ecologically relevant situation. Also, because algal and dace responses are similar following successive floods in these mesocosms (Bertrand et al. 2009), our effort was concentrated on creating gradients of conditions following a single flood rather than on creating less-diverse conditions following multiple floods.

Conditions in mesocosms were varied along gradients of 6 dace densities and 6 nutrient concentrations in a factorial design. $\mathrm{N}$ (as $\mathrm{KNO}_{3}{ }^{-}$) additions were used to create target concentrations of 30 (ambient), 60, 120, 240, 500, and $1000 \mu \mathrm{g} / \mathrm{L} \mathrm{NO}_{3}{ }^{-} \mathrm{N}$, and $\mathrm{P}$ (as $\left.\mathrm{KH}_{2} \mathrm{PO}_{4}\right)$ was added in a $16: 1(\mathrm{~N}: \mathrm{P})$ molar ratio. Each nutrient concentration treatment was replicated in 6 mesocosms. Nutrients were added continuously by pumping a concentrated solution into the springwater delivery pipes with FMI metering pumps (model QBG; Fluid Metering Inc., Syosset, New York) at a rate of $5 \mathrm{~mL} / \mathrm{min}$ from an 18-L sealed bucket (Fig. 1). The solution was mixed completely with the incoming spring water before entering the mesocosms. Buckets were cleaned and refilled every $2 \mathrm{~d}$. Inflow nutrient concentrations in each nutrient treatment were measured every $2 \mathrm{~d}$, and nutrient concentrations in each pool were measured every $7 \mathrm{~d}$. Inflows were adjusted daily to maintain equal water volume input in all streams. Daily nutrient- loading rates for each mesocosm were calculated from inflow volume and nutrient concentrations.

Dace were stocked at 6 densities, 0, 10, 20, 30, 40, and 50 individuals/mesocosm (average $1 \mathrm{~g}$ wet mass/dace, 0-15 g wet mass $/ \mathrm{m}^{2}$ ), directly after flooding to minimize fish loss during flooding and to ensure that treatments began at desired densities. Densities were based on the range that typically occur in nearby Kings Creek (Franssen et al. 2006, Bertrand and Gido 2007) and are similar to densities reported for this species in other prairie streams (Stasiak 2007). Each dace density treatment was replicated once at each nutrient concentration, and combinations of nutrient and density treatments were assigned randomly to mesocosms. Dead dace $(<1 \%$ daily death rate) were replaced daily to maintain initial densities.

\section{Response variables}

Mesocosm ecosystem structural and functional responses were measured on day 2 and then every $7 \mathrm{~d}$ for $35 \mathrm{~d}$. Benthic algae accumulation in nearby Kings Creek typically peaks 4 to $5 \mathrm{wk}$ after a flood (Murdock and Dodds 2007). Structural variables measured in pools and riffles were algal biomass, algal filament length, total benthic organic matter (BOM), and average BOM particle size. Functional variables measured were areal- and biomass-specific gross primary productivity (GPP), community respiration $(\mathrm{CR})$, and nutrient retention as $\mathrm{TN}$. On each sampling date, algal biomass (as mg chlorophyll $a / \mathrm{m}^{2}$ ) was measured from 3 rocks in each riffle and from 5 
rocks in each pool. Rocks were collected without bias and were placed on ice and frozen within $4 \mathrm{~h}$ of collection. In the laboratory, rocks were put in an autoclavable bag and submerged in 95\% ethanol at $78^{\circ} \mathrm{C}$ for $5 \mathrm{~min}$. Pigments were extracted in the dark for $12 \mathrm{~h}$ at $4^{\circ} \mathrm{C}$ (Sartory and Grobbelaar 1984). Chlorophyll $a$ (chl) content of the extract was measured on a Turner model 112 fluorometer (Turner Designs, Sunnyvale, California) with a filter set and lamp that did not allow phaeophytin interference (Welschmeyer 1995). Rock areas (projectional) were measured by tracing the top surface of the rock on paper, digitizing the image, and determining the area of the tracing with SigmaScan 5 (Systat Software Inc., San Jose, California). Algal filament lengths in riffles were measured at 3 points along 3 equally spaced transects oriented perpendicular to flow. Filament lengths in the pool were measured at 4 points around the outer perimeter and 1 in the center.

BOM was collected with a core sampler consisting of a $0.018-\mathrm{m}^{2}$ tin pipe with an electric pump $(0.1 \mathrm{~L} / \mathrm{s})$ attached through the side. Substrata inside the corer were agitated by hand while $9 \mathrm{~L}$ of water were collected in a bucket. Bucket contents were homogenized and a 500-mL subsample was collected and preserved with formalin. Ash-free dry mass of BOM was measured for 5 size classes $(>500 \mu \mathrm{m}, 499$ $250 \mu \mathrm{m}, 249-180 \mu \mathrm{m}, 179-100 \mu \mathrm{m}$, and $99-1 \mu \mathrm{m})$ by filtering through a series of sieves.

Whole-stream GPP and CR were estimated by measuring diurnal changes in dissolved $\mathrm{O}_{2}$ (DO) concentrations (Bott 2006). Every 7 d, hourly DO and temperature measurements in each mesocosm were taken with a handheld DO meter (model 550a; Yellow Springs Instruments, Yellow Springs, Ohio) from $1 \mathrm{~h}$ before sunrise to $1 \mathrm{~h}$ after sunset and then the following morning at sunrise. Aeration was measured in 3 mesocosms run at the same flow rates and substrata arrangement as the experiment by the propane-injection method (Marzolf et al. 1994, Young and Huryn 1998) and was assumed to be the same in all mesocosms. Hourly solar radiation was measured in an open area $300 \mathrm{~m}$ away (data available at www. konza.ksu.edu). Light intensity differed among sampling dates, so daily areal GPP measurements were light-corrected and calculated as a photosynthetic yield (GPP:PAR [photosynthetically active radiation]; g $\mathrm{O}_{2} / \mathrm{mol}$ quanta). Biomass-specific GPP was calculated from light-corrected GPP and combined pool and riffle chl $\left(\mathrm{g} \mathrm{O}_{2} / \mathrm{m}^{2} / \mathrm{mol}\right.$ quanta $\left./ \mathrm{mg} \mathrm{chl}\right)$. Mesocosm nutrient retention was calculated as the proportion of $\mathrm{TN}$ and $\mathrm{TP}$ loading removed from the water each sampling date (e.g., TN in inflow [ $\mu \mathrm{g}$ $\left.\mathrm{TN} \mathrm{L}^{-1} \mathrm{~d}^{-1}\right]-\mathrm{TN}$ in outflow/TN in inflow). Thus, a proportion $=1$ means all inflowing $\mathrm{TN}$ was removed from the water, and a proportion $<0$ means water TN concentrations were greater than inflow concentrations. Atmospheric $\mathrm{N}$ deposition into mesocosms was not accounted for in TN retention calculations.

Dace excretion rates $\left(\mathrm{NH}_{4}{ }^{+}\right.$and DRP) were measured on day 21. Three dace from each mesocosm were collected with a backpack electroshocker and placed in spring water for 15 to $30 \mathrm{~min}$. Excretion was measured by placing the 3 dace from each mesocosm (mean length $=51 \mathrm{~mm}$ ) in 1-L bottles filled with $800 \mathrm{~mL}$ of filtered spring water. A background nutrient sample was collected before dace additions. Water samples were taken every $15 \mathrm{~min}$ for $1 \mathrm{~h}$ and were immediately placed on ice and frozen within $4 \mathrm{~h}$. $\mathrm{NH}_{4}{ }^{+}$concentrations were analyzed with the indophenol-blue method, and DRP concentrations were analyzed with the ascorbic acid method on an OI Analytical Flow Solution IV autoanalyzer (OI Analytical, College Station, Texas; APHA 1998). Excretion rates were calculated as the slope of the regression for increase in $\mathrm{NH}_{4}{ }^{+}$or DRP over time and were converted to $\mathrm{mg} \mathrm{N}$ or $\mathrm{P} / \mathrm{d}$ (the rates were assumed to be constant over the day).

\section{Data analyses}

Multiple regression analysis was used to investigate if fish density, nutrient loading, time since flood, or a combination of these variables was the best predictor of structural and functional variation (i.e., explained the most variation in the response variable $\left.\left[R^{2}\right]\right)$. A cross-product term was added to the regression equation to test for 2-way interactions (i.e., nonlinear relationships) among fish, nutrients, and day since flood. TN was used for the nutrient term because TP had no significant relationships with any response variable across nutrient-loading treatments. Response-variable and TN loading data were $\log _{10}(\mathrm{x})$ transformed to homogenize variances across sampling dates. TN loadings were calculated as the mean loading rate from all days prior to that sampling time to integrate day-to-day variations in inflow volumes and nutrient input. For each response variable, the full model was: response variable $=$ intercept $+\mathrm{D}+\mathrm{F}$ $+\mathrm{N}+(\mathrm{F} \times \mathrm{N})+(\mathrm{F} \times \mathrm{D})+(\mathrm{N} \times \mathrm{D})+$ error where $\mathrm{N}$ is mean TN load, $\mathrm{F}$ is fish density, and $\mathrm{D}$ is day since flood.

An information-theoretic approach was used to compare candidate regression models and to assess which factors and interactions were important in predicting a response variable. Candidate models consisted of all possible combinations of the full model because the full model contained only manip- 
TABLE 1. Best approximating models for predicting structural and functional response variables in mesocosms as determined by Akaike Information Criterion for small sample sizes (AICc) values. Intercept and error terms also were included in all models. $\mathrm{DN}=$ day $\times$ nutrient interaction, $\mathrm{DF}=$ day $\times$ fish interaction, $\mathrm{NF}=$ nutrient $\times$ fish interaction, $w_{i}=\mathrm{Akaike}$ weighting, $\mathrm{K}=$ number of parameters in model, $\Delta_{i}=$ difference in AICc of model from the best model. Only models with a $\Delta_{i} \leq 2$ (suggesting strong evidence of support) are presented. GPP $=$ gross primary productivity, $\mathrm{BOM}=$ benthic organic matter, $\mathrm{TN}=$ total $\mathrm{N}$.

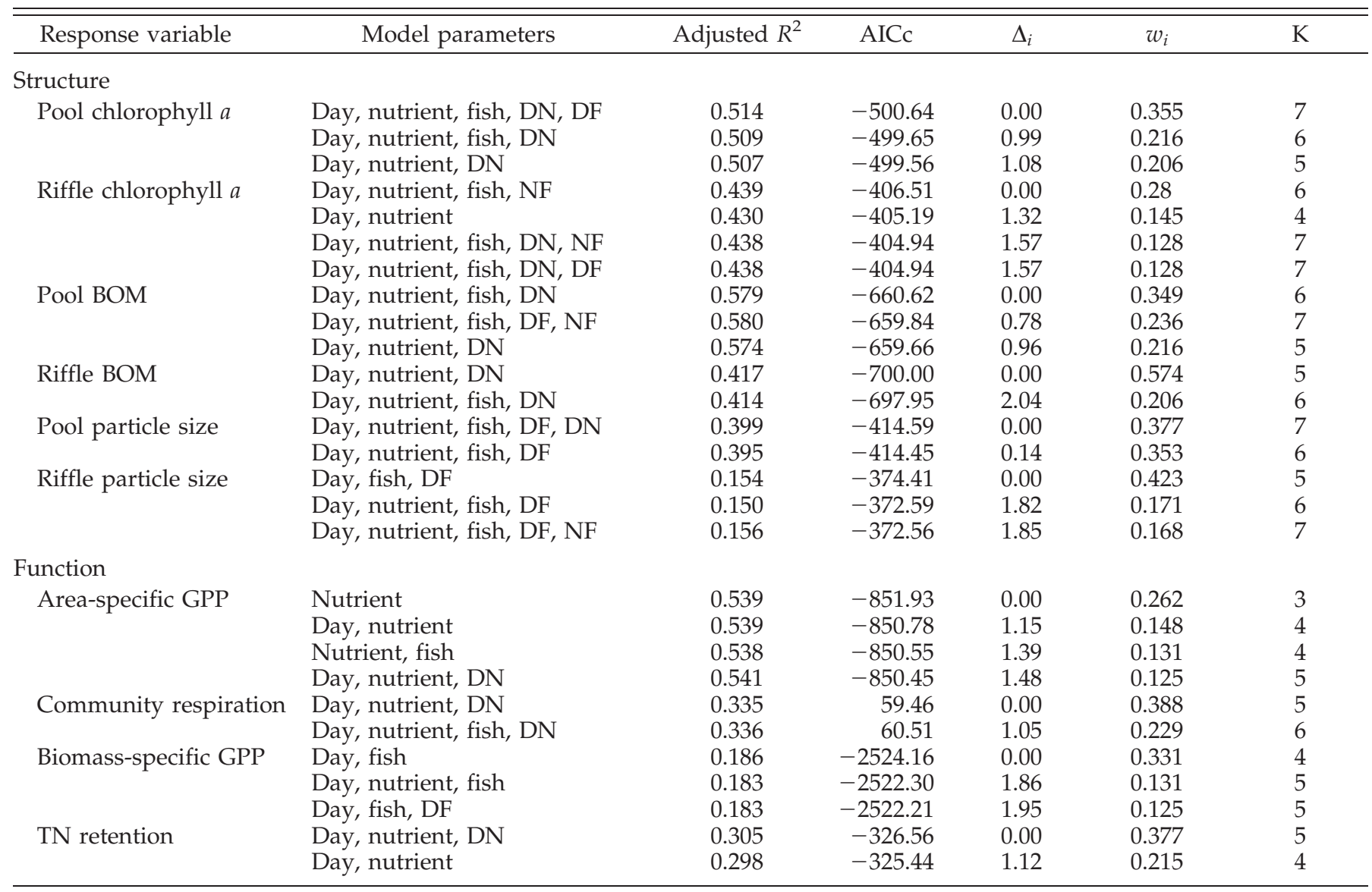

ulated variables and their interactions. The smallsample size adjustment of Akaike's Information Criterion (AICc; Akaike 1973) was used to rank models by the difference between the AICc value for each candidate model and the model with the lowest AICc value. The Akaike weight of evidence $\left(w_{i}\right)$, which gives the probability that a model is the best model for the data relative to the highest-ranked model, was calculated for each model (Burnham and Anderson 1998). Only models with $w_{i}>10 \%$ of the $w_{i}$ of the best model, which can be considered as all models within the $90 \%$ confidence interval of the best approximating model, were compared (Royall 1997). For each response variable, the relative importance of individual parameters was assessed by summing the $w_{i}$ s of candidate models that contained the variable of interest (Burnham and Anderson 1998). Multiple regression and AIC analyses were done in SAS (version 9.2; SAS Institute Inc., Cary, North Carolina).
A quadratic surface response curve was fit to each variable to assess which combinations of nutrients and fish density produced minima and maxima of each variable (JMP version 8; SAS Institute Inc., Cary, North Carolina). The global model used was: response variable $=$ intercept $+\mathrm{N}+\mathrm{F}+\mathrm{D}+\mathrm{N}^{2}+\mathrm{F}^{2}+\mathrm{D}^{2}$ $+(\mathrm{N} \times \mathrm{F})+(\mathrm{D} \times \mathrm{F})+(\mathrm{N} \times \mathrm{D})+$ error. Second-order terms were used because nonlinear relationships (interactions) in parameters were found with multiple regression analysis.

\section{Results}

Nutrient loading, dace density, day since flood, and their interactions explained 15 to $58 \%$ of the variation in structural variables and $\sim 19$ to $\sim 54 \%$ in functional variables (Table 1). Nutrient loading was a stronger regulator of recovery than was dace density for most variables, and the influence of both factors changed 

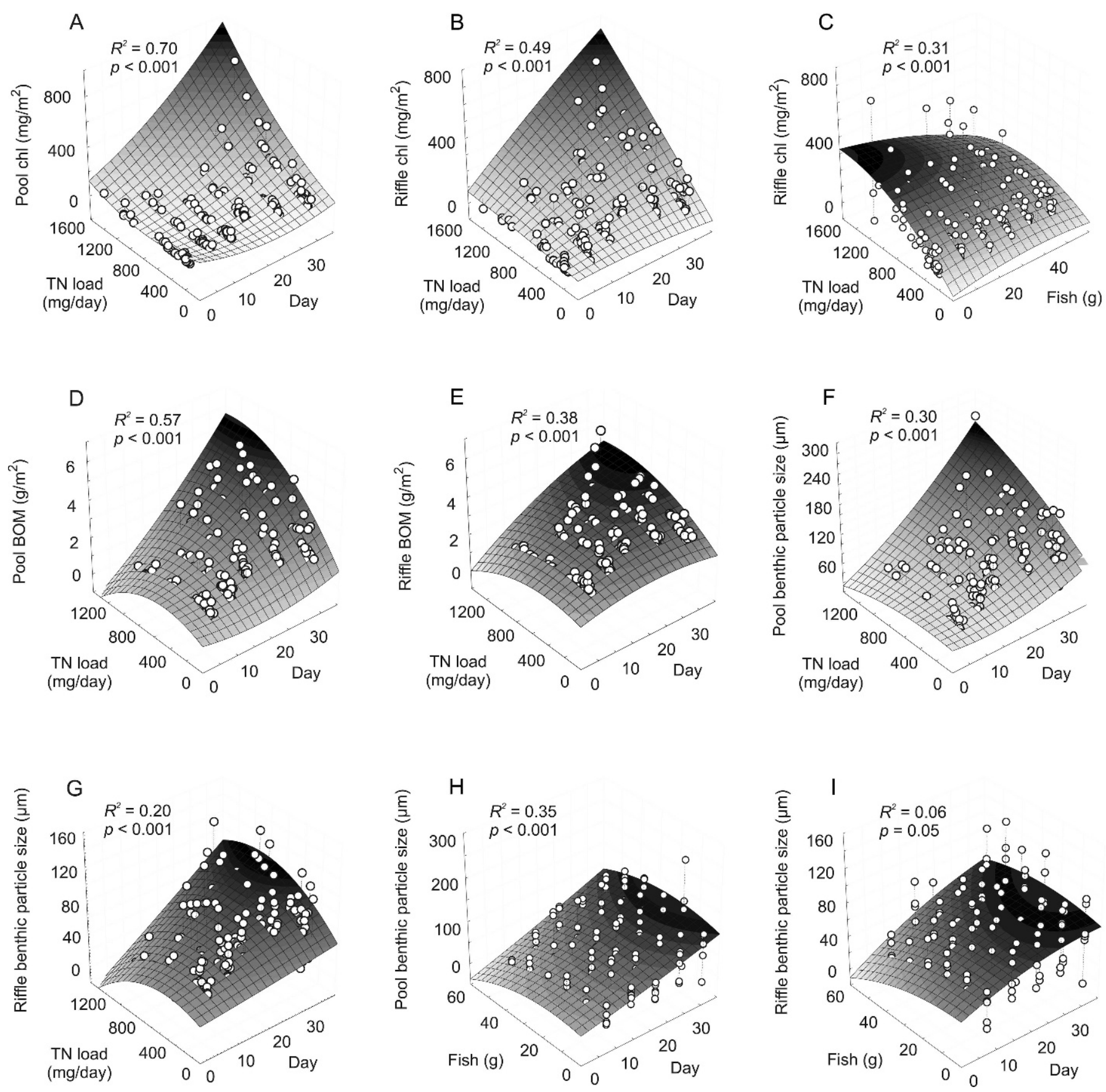

FIG. 2. Response curves showing the relationships of structural variables with nutrient loading as total N (TN), fish (dace) density, and time since flood (day). A.-Pool algal biomass (as chlorophyll $a$ [chl]). B.-Riffle algal biomass. C.-Riffle algal biomass. D.-Pool benthic organic matter (BOM). E.-Riffle BOM. F.-Pool benthic particle size. G.—Riffle benthic particle size. H.-Pool benthic particle size. I.-Riffle benthic particle size. Data were fit with a quadratic surface.

during recovery (Figs 2A-I, 3A-D, Table 1). Nutrient loading and day since flood were included in the best model for every response variable except riffle BOM particle size and biomass-specific GPP (Table 1) and consistently had higher $w_{i}$ and relative importance values than dace density (Table 2). Dace influence was not strong during recovery, but dace were included in the best approximating model for 5 of 6 structural variables and for biomass-specific GPP. Relative importance values suggested that dace had a negative effect on structural variables and on $C R$ (Table 2). Interactions among nutrients, dace, and 
A

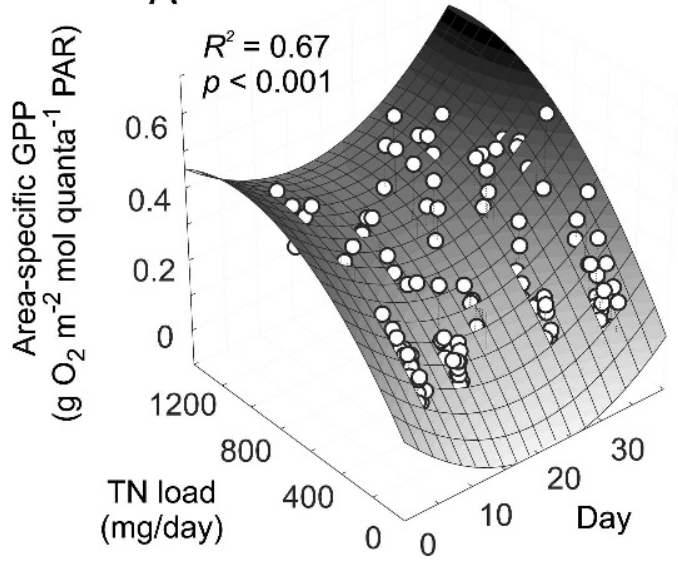

C

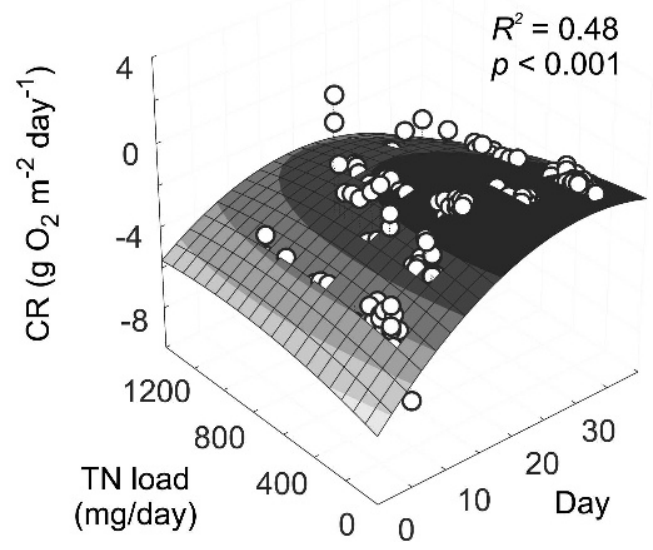

B
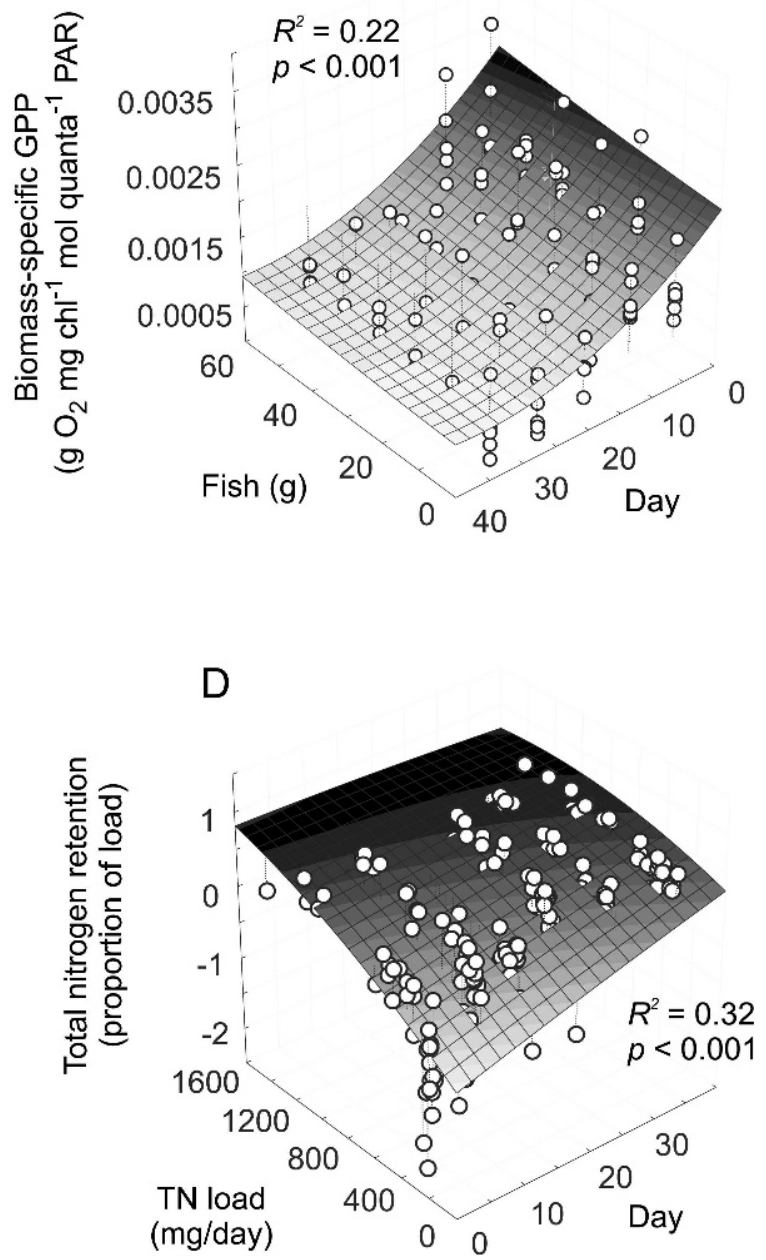

FIG. 3. Response curves showing the relationships of functional variables with nutrient loading as total N (TN) load, fish (dace) density, and time since flood (day). A.-Area-specific gross primary productivity (GPP). B.-Biomass-specific GPP (note day scale is reversed). C.-Community respiration (CR; note negative values denote increased CR). D.-Nutrient retention (proportion of TN retained). Data were fit with a quadratic surface. PAR $=$ photosynthetically active radiation, chl $=$ chlorophyll $a$.

time during recovery were also important. Nutrient influence changed over time for 6 of 10 response variables (interaction included in the best model), whereas dace influence changed over time for 3 variables and across nutrients for 1 variable (see Table 1).

\section{Structural recovery}

Algae.-Nutrient loading, dace density, day since flood, and their interactions explained $\sim 51 \%$ and $\sim 44 \%$ of the variation in algal biomass in pools and riffles, respectively, and biomass was better correlated with nutrients and day than with dace (Table 1 , Fig. 2A-C). Pool algal biomass accrued in 2 distinct temporal stages. Across all fish densities, days 1 to 14 were characterized by low biomass (average $<50 \mathrm{mg}$ $\mathrm{chl} / \mathrm{m}^{2}$ ) in all except the highest nutrient treatment (average $>100 \mathrm{mg} \mathrm{chl} / \mathrm{m}^{2}$ ). Biomass increased rapidly during days 14 to 35 and accumulated proportionately with nutrient loading (Table 3). Riffle algal biomass increased logarithmically in all nutrient treatments with similar peak biomass when TN loading was $<574 \mathrm{mg} / \mathrm{d}$ and greater biomass at higher loading rates (Table 3 ). Both riffle and pool algae were dominated by green filamentous algae (Spirogyra sp., Oedogonium sp., and Microspora sp.) and pennate diatoms (Synedra sp. and Fragilaria sp.).

Despite dominant nutrient and day effects, dace also influenced algal recovery. The best pool algalbiomass models, which included dace, were $1.7 \times$ (in pools) and $1.9 \times$ (in riffles) more likely than the best candidate model that did not include dace. Dace 
TABLE 2. Cumulative Akaike's Information Criterion for small sample size (AICc) weights giving the relative importance of each model parameter for each response variable. $\mathrm{DN}=$ day $\times$ nutrient interaction, $\mathrm{DF}=$ day $\times$ fish interaction, $\mathrm{NF}=$ nutrient $\times$ fish interaction. Variables with a negative relative importance factor had a negative effect on the response variable. Values calculated from all models with AICc weight of evidence $>10 \%$ of that of the best model. BOM $=$ benthic organic matter, GPP $=$ gross primary production, $\mathrm{TN}=$ total $\mathrm{N}$.

\begin{tabular}{|c|c|c|c|c|c|c|}
\hline Response variable & \multicolumn{6}{|c|}{ Relative importance } \\
\hline Pool chlorophyll $a$ & 0.98 & 0.98 & -0.77 & 0.98 & 0.48 & -0.20 \\
\hline Pool BOM & 1.00 & 1.00 & -0.78 & 0.55 & 0.44 & -0.32 \\
\hline Riffle BOM & 0.96 & 0.96 & -0.39 & 0.89 & -0.18 & -0.07 \\
\hline Pool particle size & 0.99 & 0.99 & -0.99 & 0.26 & 0.87 & -0.64 \\
\hline Community respiration & 1.00 & -0.93 & -0.52 & -0.74 & 0.22 & -0.13 \\
\hline Biomass-specific GPP & -1.00 & -0.97 & 0.99 & -0.96 & -0.11 & -0.10 \\
\hline TN retention & 0.92 & 0.91 & 0.32 & -0.51 & -0.11 & -0.05 \\
\hline
\end{tabular}

effects on algae were generally nutrient- or timedependent. The nutrient $x$ dace interaction was significant for riffle algal biomass. Dace slightly increased algal biomass at low nutrient loadings but decreased biomass at high nutrient loadings (Fig. 2C). Also, dace significantly reduced algal filament lengths at ambient nutrient loadings in pools $(0.39 \mathrm{~cm} / \mathrm{g}$ wet mass $[\mathrm{WM}]$ dace, $r^{2}=0.20, p=0.01$ ) and riffles $\left(0.48 \mathrm{~cm} / \mathrm{g} \mathrm{WM}\right.$ dace, $\left.r^{2}=0.20, p=0.01\right)$, but had no effect on filament length at high nutrient loadings (data not shown). Dace had the strongest negative influence (reducing pool algal biomass) during days 1 to 14 when algal biomass was low. However, across all treatment combinations, this relationship was very weak $\left(r^{2}=0.03, p=0.06\right)$, and dace did not affect algal biomass during days 21 to 35 .

Benthic organic matter and particle size.-Nutrient loading and day since flood had a strong positive influence on pool and riffle BOM accumulation (Fig. 2D, E). Slightly more of the variance in BOM was explained in pools (58\%) than in riffles $(42 \%)$.
Nutrients, day, and a nutrient $\times$ day interaction were the best predictors of BOM in both locations (Table 1). $\mathrm{BOM}$ accumulation was initially low in all treatments and increased proportionately with higher nutrient availability over time. Dace decreased BOM accumulation in pools more than in riffles. Dace density was included in the best model for pools, and was $1.6 \times$ more likely to be the best model than when dace were not included. In contrast, the best riffle BOM model was $2.8 \times$ more likely to be the best model than the same model with dace included.

Benthic particle size generally increased over time. Nutrients had a positive effect (Fig. 2F, G), and dace had a negative effect early (Fig. 2H, I). Day since flood, dace density, and their interaction were the best predictors of benthic particle size in riffles. Nutrients also were important in pools (Table 1). Dace had the strongest negative effect early in recovery because dace slightly decreased mean particle size in riffles through day 7 and in pools through day 14, but dace did not have an effect thereafter.

TABLE 3. Mean ( \pm SD) pool and riffle daily algal accumulation rates for each nutrient treatment during early (days 1-14), and late (days 14-35) recovery in mesocosms. chl $=$ chlorophyll $a$.

\begin{tabular}{|c|c|c|c|c|}
\hline \multirow{3}{*}{$\begin{array}{c}\mathrm{NO}_{3}{ }^{-}-\mathrm{N} \text { loading } \\
(\mathrm{mg} / \mathrm{d})\end{array}$} & \multicolumn{4}{|c|}{ Daily algal accumulation ( $\mathrm{mg} \mathrm{chl} \mathrm{m}^{-2} \mathrm{~d}^{-1}$ ) } \\
\hline & \multicolumn{2}{|c|}{ Pool } & \multicolumn{2}{|c|}{ Riffle } \\
\hline & Days $1-14$ & Days $14-35$ & Days 1-14 & Days $14-35$ \\
\hline 69 & $0.26(0.56)$ & $0.67(0.71)$ & $2.13(0.84)$ & $-0.07(1.03)$ \\
\hline 103 & 0.71 (1.15) & $3.56(1.71)$ & $1.83(3.27)$ & 4.47 (4.99) \\
\hline 125 & $0.36(1.58)$ & $1.71(1.28)$ & $3.30(2.74)$ & 4.47 (1.25) \\
\hline 707 & 1.19 (1.98) & 18.51 (11.35) & 8.92 (3.51) & $4.51(7.75)$ \\
\hline
\end{tabular}


TABLE 4. Mean ( \pm SD) nutrient-loading rates and mesocosm water concentrations. Total P (TP) from inflow loading was not measured directly and was estimated as dissolved reactive P $(\mathrm{DRP})+$ mean TP in unaltered spring water. $\mathrm{BD}=$ below detection $(1 \mu \mathrm{g} / \mathrm{L})$.

\begin{tabular}{|c|c|c|c|c|}
\hline Variable & \multicolumn{4}{|c|}{ Nutrient } \\
\hline \multicolumn{5}{|c|}{ Inflow loading (mg/d) } \\
\hline $\begin{array}{c}\text { Nutrient treatm } \\
1 \\
2 \\
3 \\
4 \\
5 \\
6\end{array}$ & $\begin{aligned} & 69(16) \\
& 103(52) \\
& 125(37) \\
& 191(212) \\
& 407(177) \\
& 707(348)\end{aligned}$ & $\begin{array}{l}233(51) \\
256(74) \\
281(60) \\
341(93) \\
574(185) \\
857(345)\end{array}$ & $\begin{array}{l}22(5.6) \\
19(7.0) \\
19(5.5) \\
19(6.7) \\
26(7.4) \\
32(10.9)\end{array}$ & $\begin{array}{l}27(6.7) \\
24(8.6) \\
24(6.9) \\
24(8.0) \\
32(8.5) \\
37(12)\end{array}$ \\
\hline \multicolumn{5}{|c|}{ Mean mesocosm nutrients $(\mu \mathrm{g} / \mathrm{L})$} \\
\hline $\begin{array}{l}\text { Nutrient treatm } \\
\quad 1 \\
2 \\
3 \\
4 \\
5 \\
6\end{array}$ & $\begin{array}{c}14(20) \\
26(44) \\
33(54) \\
27(37) \\
75(95 \\
194(203)\end{array}$ & $\begin{array}{l}208(151) \\
207(69) \\
277(146) \\
236(150) \\
247(104) \\
291(141)\end{array}$ & $\begin{array}{l}\mathrm{BD} \\
\mathrm{BD} \\
\mathrm{BD} \\
\mathrm{BD} \\
\mathrm{BD} \\
\mathrm{BD}\end{array}$ & $\begin{array}{l}5.7(10.5) \\
3.3(2.7) \\
5.5(6.3) \\
4.9(3.5) \\
4.3(4.9) \\
4.4(3.5)\end{array}$ \\
\hline $\begin{array}{l}\text { Fish (number o } \\
0 \\
10 \\
20 \\
30 \\
40 \\
50\end{array}$ & $\begin{array}{l}61(110) \\
60(101) \\
36(69) \\
70(165) \\
68(116) \\
71(110)\end{array}$ & $\begin{array}{l}296(180) \\
218(84) \\
261(134) \\
179(60) \\
213(72) \\
272(131)\end{array}$ & $\begin{array}{l}\text { BD } \\
\text { BD } \\
\text { BD } \\
\text { BD } \\
\text { BD } \\
\text { BD }\end{array}$ & $\begin{array}{l}6.6(11.4) \\
4.3(3.7) \\
5.6(4.7) \\
2.7(2.1) \\
3.7(2.5) \\
5.2(4.7)\end{array}$ \\
\hline
\end{tabular}

\section{Functional recovery}

Metabolism.-Area-specific GPP remained relatively constant over time in each nutrient treatment, and biomass-specific GPP and CR decreased during recovery. Nutrient loading accounted for most of the explained variance in area-specific GPP $\left(R^{2} \approx 0.54\right.$, $p<0.001$, Table 1, Fig. 3A). However, nutrients were not a significant predictor of biomass-specific GPP $\left(R^{2}\right.$ $=0.001, p=0.62)$, which was more closely correlated to day since flood and dace density $\left(R^{2}=0.20, p<\right.$ 0.001 ; Table 1, Fig. 3B). Dace generally had a positive effect on biomass-specific GPP. Community respiration was most closely associated with nutrients, day since flood, and their interaction $\left(R^{2}=0.34, p<0.001\right.$; Table 1). Community respiration decreased over time, but less so with higher nutrient loading (Fig. 3C; greater negative values denote greater respiration). Relative AICc importance values for each factor suggested that the recovery of stream metabolism was regulated more by nutrient availability and day since flood than by dace, which was $\sim 1 / 2$ as important (Table 2).

Nutrients.-Nutrient loadings were consistent throughout the experiment. However, nutrient pumps failed during days 13 and 14 in all treatments. The pump malfunction caused a $22 \%$ reduction in $\mathrm{TN}$ loading from day 7 to 14 in the highest nutrient treatment, resulting in an overall maximum $4 \%$ reduction in loading in this treatment. Strong trends in TN were observed, but TP did not show significant trends across nutrient or fish treatments or over time. TP loadings were similar in the 4 lower nutrient treatments and did not maintain a 16:1 increase with TN (Table 4). Biofilm growth was observed in the delivery tubing and may have removed some of the $\mathrm{P}$ before it entered mesocosms. Alternatively, given the relatively high $\mathrm{pH}$ and alkalinity of mesocosm water, some $\mathrm{P}$ could have precipitated out of solution. P input was greater in the higher than in the lower nutrient-loading treatments, but DRP was consistently below detection $(<1 \mu \mathrm{g} / \mathrm{L})$ and $\mathrm{TP}$ was relatively constant across all nutrient treatments.

TN retention was more strongly influenced by nutrient loading and day since flood than by dace density (Table 1, Fig. 3D). The best TN retention model, which included nutrients, day since flood, and a nutrient $\times$ day interaction, was $2.8 \times$ more likely to be the best model than the highest-ranked model that included dace. Absolute TN retention $(\mu \mathrm{g}$ 

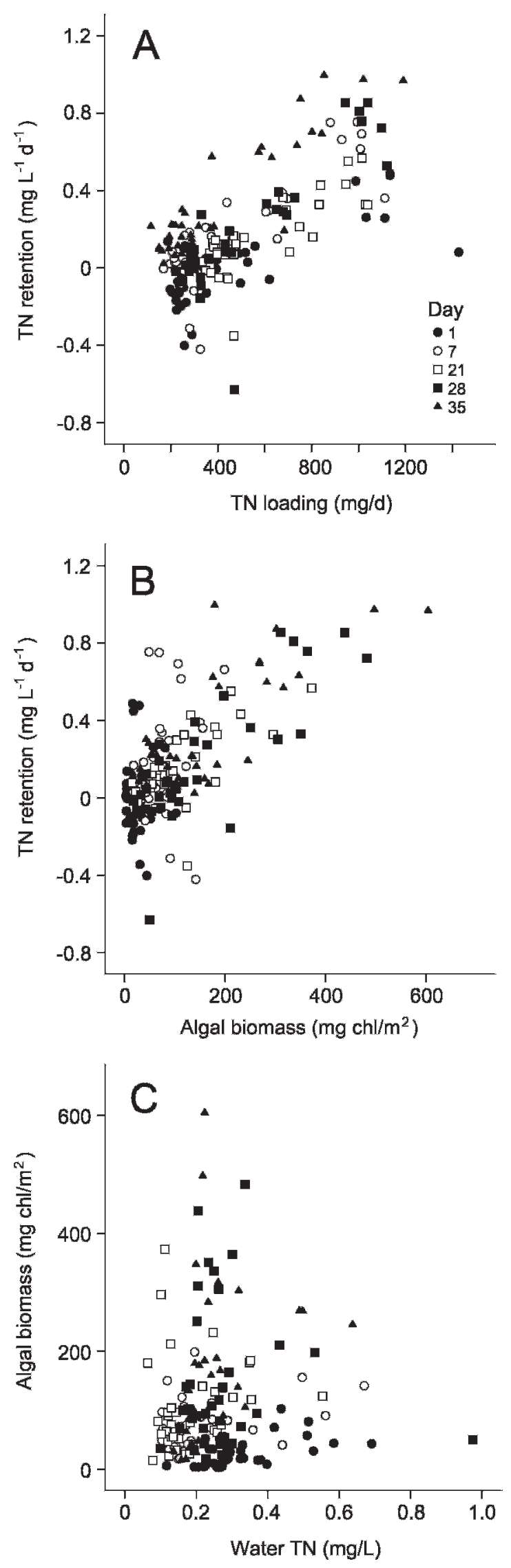

TN L ${ }^{-1} \mathrm{~d}^{-1}$ ) increased with increasing TN loading rates $\left(r^{2}=0.51, p<0.001\right.$ and over time, excluding day 14; Fig. 4A), but retention had an inconsistent relationship with water TN concentration. Absolute TN retention was correlated with algal biomass $\left(r^{2}=\right.$ $0.47, p<0.001$, excluding day 14; Fig. 4B), and algae appeared to have mediated stream-water TN. For example, high stream-water TN concentrations occurred with high loading rates and low algal biomass (i.e., during early recovery in high-nutrient treatments). Low stream-water TN concentrations were associated with high loading rates and high algal biomass (later recovery in high-nutrient treatments), and low loading rates with low algal biomass (low nutrient treatments throughout recovery; Fig. 4C). In addition, low-nutrient mesocosms were net sources of TN for approximately the first $14 \mathrm{~d}$ of recovery (Fig. 3D).

Average dace $\mathrm{N}$ excretion rates were $0.62(\mathrm{SD}=$ $0.28) \mathrm{mg} \mathrm{N} \mathrm{g}^{-1} \mathrm{WM} \mathrm{d}^{-1}$ and were not significantly different among treatments. $\mathrm{N}$ excretion from dace ranged from a relatively small fraction of total loading rates $(<1 \%$ with lowest fish density and highest nutrient loading) up to $\sim 45 \%$ of $\mathrm{N}$ loading with maximum fish density and ambient nutrient loading (Table 5). However, no difference in water-column N concentrations was observed across fish treatments (Table 4). Dace did not excrete measureable DRP.

\section{Discussion}

Streams can be characterized with respect to autotrophic and heterotrophic states (Dodds 2007, Dodds and Cole 2007). Our study suggests that floods have a negative effect on autotrophic state (GPP) but a positive effect on heterotrophic state (CR). The recovery of both was strongly influenced by nutrient concentration. Dace had a secondary influence on GPP but not on CR. This result might indicate that CR and GPP can be decoupled after a flood and that a substantial proportion of $C$ flux to the systems was not provided by current autotrophic production, despite high algal accumulation rates. Remnants of preflood autotrophic production could contribute to postflood heterotrophic production. Our data suggest

FIG. 4. Relationships among total N (TN) loading, TN retention, and algal biomass across all treatments and sample dates. A.-Absolute TN retention vs TN loading. B.-Absolute TN retention vs algal biomass. C.-Algal biomass vs stream-water TN concentration. Day 14 data excluded. 
TABLE 5. Comparison of fish $\mathrm{N}$ excretion rates across nutrient treatments. Values are $\%$ dissolved $\mathrm{N}$ of inflow loading that fish excreted. In the $1^{\text {st }}$ column, values in parentheses are number of fish in mesocosm.

\begin{tabular}{|c|c|c|c|c|c|c|}
\hline \multirow{2}{*}{$\begin{array}{l}\text { Fish } \mathrm{N} \text { excretion } \\
\text { in mesocosms } \\
(\mathrm{mg} \mathrm{N} / \mathrm{d})\end{array}$} & \multicolumn{6}{|c|}{$\mathrm{NO}_{3}-\mathrm{N}$ loading $(\mathrm{mg} \mathrm{N} / \mathrm{d})$} \\
\hline & 69 & 103 & 125 & 191 & 407 & 707 \\
\hline $6.2(10)$ & 9.0 & 6.0 & 4.9 & 3.2 & 1.2 & 0.9 \\
\hline $12.4(20)$ & 17.9 & 12.0 & 9.9 & 6.5 & 3.0 & 1.7 \\
\hline $18.5(30)$ & 26.9 & 18.0 & 14.8 & 9.7 & 4.6 & 2.6 \\
\hline
\end{tabular}

that both top-down and bottom-up factors may influence autotrophic and heterotrophic states in nonequilibrium systems.

Both nutrient loading and fish density influenced periphyton recovery from flooding in mesocosms, but in contrast to general patterns observed in streams, where grazers often regulate benthic structure (see reviews by Feminella and Hawkins 1995, Hillebrand 2002, 2009, Gruner et al. 2008), nutrient influence was much stronger than fish influence. Simulated floods quickly changed the physical, biological, and chemical makeup of mesocosms and created a dynamic producer:consumer ratio as algal biomass increased over time. Top-down and bottom-up effects on stream algae can vary with biotic and abiotic variables in a system (Rosemond et al. 1993, Murdock et al. 2004, Hillebrand 2009), so flooding probably caused the influence of nutrients and consumers (and their interactions) on algae to change during recovery.

\section{Dace role after flood}

Dace influenced algal development, but their effect was weak within the typical biomass range found in nearby Kings Creek and other prairie streams (Stasiak 2007). Our mesocosm results were consistent with a weak dace effect on recovery of adnate, diatomdominated algal assemblages in Kings Creek after a flood (Bertrand et al. 2009). Dace effects in mesocosms were weak but consistent with previous findings for effects of stream grazing fish that included decreased algal biomass, filament lengths, and benthic particle size (Power and Matthews 1983, Power et al. 1988b, Bertrand and Gido 2007) and increased biomassspecific GPP (Gelwick and Matthews 1992). Moreover, attenuation of grazer influence also is consistent with results from Gelwick and Matthews (1992), who measured the effects of central stoneroller (Campostoma anomalum) over time.

The relative importance of dace excretion to algal accumulation was minimal during recovery. The strongest positive dace effect was increased algal biomass in riffles at low nutrient loading. Dace fed predominantly in pools or at the base of riffles rather than in the riffles, and BOM and particle size decreased more in pools than in riffles. Dace can alter benthic particle size by physically breaking down larger particles while feeding and egesting digested fine organic material. This reduction in particle size can alter benthic processes (smaller particles often are more consumable by macroinvertebrates) and can hasten bacterial breakdown of organic matter. This habitat preference may have led to greater biomass removal in pools than in riffles and increased nutrient translocation from pools to riffles. Fish can move nutrients within systems (Meyer et al. 1983, Vanni 2002, Vanni et al. 2006, Hall et al. 2007), a process that can spatially decouple a fish's location and its effect. In natural streams with pool-riffle structure, this process might increase algal biomass in the riffle downstream of the pool, but in recirculating mesocosms, nutrient translocation probably increased nutrient availability in upstream riffles.

Net grazer influence on algal biomass is a result of the balance of removal and stimulation, and algal stimulation by grazers in streams probably requires a narrow range of conditions, including nutrient-limited algal growth and low-to-moderate grazer density (Lamberti et al. 1989, Steinman 1996, Vanni 2002). In high-dace/low-nutrient mesocosms, dace potentially released a substantial proportion of the available dissolved $\mathrm{N}$, but algal stimulation was minimal and elevated $\mathrm{N}$ in the water column was not observed. It is possible that algal stimulation and removal rates were similar. Grazer stimulation of algal growth (and biomass-specific GPP) also can be caused by the replacement of older, lower-quality algae with moreproductive cells (Lamberti et al. 1989). This mechanism may not be as important following floods because early-succession algae typically are fast colonizers with high metabolic and reproductive rates (Peterson 1996). Therefore, both the grazed algae and the algae that replace it may be similar structurally 
and functionally. Measurements of dace grazing rates and mass change vs algal-biomass availability would help better determine this relative balance between removal and stimulation.

Dace reduction of macroinvertebrates may have led to a smaller dace effect during recovery. Greater macroinvertebrate grazing associated with lower dace density could lead to similar reductions in algae across dace densities. Direct macroinvertebrate measurements were not made in our study, but numerous macroinvertebrate measurements have been collected in these mesocosms following disturbance (Gido et al. 2010). The diversity and abundance of macroinvertebrates in prairie streams are both very low immediately after floods, and a few weeks are required for substantial biomass accrual (Fritz and Dodds 2004, 2005). Similar biomass and species-return patterns occur in mesocosms, and fast-reproducing species (typically chironomids) contribute the greatest biomass. Dace can reduce chironomid abundance in mesocosms (Gido et al. 2010), but presumably do so via bioturbation rather than consumption (Bertrand et al. 2009). Thus, an indirect effect of dace on macroinvertebrates may limit its influence on algal recovery after flood.

\section{Nutrient role after flood}

Nutrient loading had a greater effect on mesocosm structural and functional recovery trajectories than did dace density. Nutrient loading significantly altered recovery trajectories, a result that supports those of theoretical and empirical studies that emphasized ecosystem structure and function changes under varying productivity levels (DeAngelis 1992, Worm et al. 2002). Algal development often is driven by nutrient availability, which can dictate both accumulation rates and maximum biomass (McCormick and Stevenson 1991, Biggs and Smith 2002, Rier and Stevenson 2006). Maximum daily accumulation rates in mesocosms varied $>7$-fold across nutrient treatments and closely matched postflood accumulation rates along a nutrient gradient in nearby Kings Creek (Bertrand et al. 2009). The observed temporally variable nutrient and algal-growth relationship during recovery complicates understanding grazer roles during nonequilibrium conditions.

During stable conditions, higher stream $\mathrm{N}$ concentration often results in greater absolute $\mathrm{N}$ uptake but lower removal efficiency (proportional retention) (O'Brien et al. 2007, Mulholland et al. 2008). In general during recovery, greater $\mathrm{TN}$ loading led to faster algal growth, greater biomass, and a correspondingly higher TN removal rate from the water. However, an inconsistent relationship between water TN con- centrations and TN loading probably was caused by the changing algal assemblage during recovery and an apparent net loss of $\mathrm{N}$ from periphyton exposed to low loading rates. Therefore, algal biomass following a disturbance may be better predicted from the mass of nutrients entering the system than from water concentrations. $\mathrm{P}$ relationships with algal growth were not as clear. However, undetectable DRP and consistently low TP concentration across nutrient treatments suggests a higher $\mathrm{P}$ demand in highnutrient treatments, possibly because of luxury consumption, or alternatively, precipitation (Dodds 2003). No correlation between $P$ and algal biomass implies that $\mathrm{N}$ may be a much stronger driver than $\mathrm{P}$ in algal recovery.

\section{Time, dace, and nutrient interactions}

Multiple nutrient and dace interactions with day since flood suggest that temporal shifts occurred in both top-down and bottom-up control of algal development during recovery. The strengths of these factors changed on a scale of weeks. In general, nutrient influence intensified with time, whereas dace influence attenuated. A weakening dace effect is contrary to the observed strong effect of grazing minnows on algal biomass during baseflow conditions in some streams (Power et al. 1988b, Gelwick and Matthews 1992), but is consistent with results reported by Murdock et al. (2010), who found decreasing large-consumer effects during prairie stream recovery from drought. Murdock et al. (2010) attributed this pattern to changing grazer communities and increasing macroinvertebrate grazing during succession. Dace appeared to have little influence on periphyton recovery because their effect was greatest soon after flooding, and the change from weak dace control to strong nutrient control coincided with the start of exponential algal growth. Anthropogenic influences include increasing nutrient concentrations and alteration of abundances of large consumers. Our results suggest that both factors can influence stream ecosystems, but the intensity of effects will vary in the context of disturbances.

\section{Acknowledgements}

We thank Jennifer Nemec and Tyler Kholer for field assistance and laboratory analyses. Katie Bertrand, Nathan Franssen, and 3 anonymous referees provided helpful suggestions on earlier versions of our manuscript. Funding was provided by the National Science Foundation, grant DEB-0416126. This is manuscript 10-275-J from the Kansas Agricultural Experiment Station. 


\section{Literature Cited}

AKAIKE, H. 1973. Information theory and an extension of the maximum-likelihood principle. Pages 267-281 in B. N. Petrov, and F. Csaki (editors). $2^{\text {nd }}$ International Symposium on Information Theory. Akademiai Kiado, Budapest, Hungary.

APHA (American Public Health Association). 1998. Standard methods for the examination of water and wastewater. $20^{\text {th }}$ edition. American Public Health Association, American Water Works Association, and Water Environment Federation, Washington, DC.

Bengtson, J. R., M. A. Evans-White, and K. B. Gido. 2008. Effects of grazing minnows (Phoxinus erythrogaster) and crayfish (Orconectes nais and O. neglectus) on stream ecosystem structure and function. Journal of the North American Benthological Society 27:772-782.

Bertrand, K. N., and K. B. Gido. 2007. Effects of the herbivorous minnow, southern redbelly dace (Phoxinus erythrogaster), on stream productivity and ecosystem structure. Oecologia (Berlin) 151:69-81.

Bertrand, K. N., K. B. Gido, W. K. Dodds, J. N. Murdock, And M. R. Whiles. 2009. Disturbance frequency and functional identity mediate ecosystem processes in prairie streams. Oikos 118:917-933.

Biggs, B. J. F., And R. A. Smith. 2002. Taxonomic richness of stream benthic algae: effects of flood disturbance and nutrients. Limnology and Oceanography 47: 1175-1186.

Botт, T. L. 2006. Primary productivity and community respiration. Pages 663-690 in F. R. Hauer, and G. A. Lamberti (editors). Methods in stream ecology. $2^{\text {nd }}$ edition. Academic Press, San Diego, California.

Burnham, K. P., And D. R. Anderson. 1998. Model selection and inference: a practical information-theoretic approach. Springer, New York.

DEANGELIS, D. L. 1992. Dynamics of nutrient cycling and food webs. Chapman and Hall, New York.

DodDs, W. K. 2003. The role of periphyton in phosphorus retention in shallow freshwater aquatic systems. Journal of Phycology 39:840-849.

DodDs, W. K. 2007. Trophic state, eutrophication, and nutrient criteria in streams. Trends in Ecology and Evolution 22:670-676.

DodDS, W. K., AND J. J. Cole. 2007. Expanding the concept of trophic state in aquatic ecosystems: it's not just the autotrophs. Aquatic Sciences 69:427-439.

Dodds, W. K., K. B. Gido, M. R. Whiles, K. M. Fritz, and W. J. Matthews. 2004. Life on the edge: the ecology of Great Plains prairie streams. BioScience 54:205-216.

Dodds, W. K., R. E. Hutson, A. C. Eichem, M. A. Evans, D. A. GUDDER, K. M. FRITZ, AND L. GRAY. 1996. The relationship of floods, drying, and light to primary production and producer biomass in a prairie stream. Hydrobiologia 333:151-159.

DodDs, W. K., V. H. Smith, AND K. Lohman. 2002. Nitrogen and phosphorus relationships to benthic algal biomass in temperate streams. Canadian Journal of Fisheries and Aquatic Sciences 59:865-874.
Feminella, J. W., and C. P. Hawkins. 1995. Interactions between stream herbivores and periphyton: a quantitative analysis of past experiments. Journal of the North American Benthological Society 14:465-509.

Flecker, A. S., B. W. Taylor, E. S. Bernhardt, J. M. Hood, W. K. Cornwell, S. R. Cassatt, M. J. Vanni, and N. S. Altman. 2002. Interactions between herbivorous fishes and limiting nutrients in a tropical stream ecosystem. Ecology 83:1831-1844.

Franssen, N. R., K. B. Gido, C. S. Guy, J. A. Tripe, S. J. Shrank, T. R. Strakosh, K. N. Bertrand, C. M. Franssen, K. L. PitTs, AND C. P. PAuKert. 2006. Effects of floods on fish assemblages in an intermittent prairie stream. Freshwater Biology 51:2072-2086.

FrITZ, K. M., AND W. K. DodDS. 2004. Resistance and resilience of macroinvertebrate assemblages to drying and flood in a tallgrass prairie stream system. Hydrobiologia 527:99-112.

FRITZ, K. M., AND W. K. DodDs. 2005. Harshness: characterization of intermittent stream habitat over space and time. Marine and Freshwater Research 56:13-23.

Gelwick, F. P., And W. J. Matthews. 1992. Effects of an algivorous minnow on temperate stream ecosystem properties. Ecology 73:1630-1645.

GIDO, K. B. 2002. Interspecific comparisons and the potential importance of nutrient excretion by benthic fishes in a large reservoir. Transactions of the American Fisheries Society 131:260-270.

Gido, K. B., K. N. Bertrand, J. N. Murdock, W. K. Dodds, And M. R. WHILEs. 2010. Disturbance-mediated effects of fishes on stream ecosystem processes: concepts and results from highly variable prairie streams. Pages 593-617 in K. Gido, and D. Jackson (editors). Community ecology of stream fishes: concepts, approaches and techniques. American Fisheries Society, Bethesda, Maryland.

Gruner, D. S., J. E. Smith, E. W. Seabloom, S. A. Sandin, J. T. Ngai, H. Hillebrand, W. S. Harpole, J. J. Elser, E. E. Cleland, M. E. S. Bracken, E. T. Borer, AND B. M. Bolker. 2008. A cross-system synthesis of consumer and nutrient resource control on producer biomass. Ecology Letters 11:740-755.

Hall, S. R., J. B. Shurin, S. Diehl, And R. M. NisBet. 2007. Food quality, nutrient limitation of secondary production, and the strength of trophic cascades. Oikos 116: 1128-1143.

HillebRAND, H. 2002. Top-down versus bottom-up control of autotrophic biomass: a meta-analysis on experiments with periphyton. Journal of the North American Benthological Society 21:349-369.

Hillebrand, H. 2009. Meta-analysis of grazer control of periphyton biomass across aquatic ecosystems. Journal of Phycology 45:798-806.

LAKE, P. S. 2000. Disturbance, patchiness, and diversity in streams. Journal of the North American Benthological Society 19:573-592.

Lamberti, G. A., S. V. Gregory, L. R. Ashrenas, A. D. Steinman, And C. D. McInTIRE. 1989. Productive capacity of periphyton as a determinant of plant herbivore interactions in streams. Ecology 70:1840-1856. 
Liess, A., AND H. Hillebrand. 2004. Invited review: direct and indirect effects in herbivore periphyton interactions. Archiv für Hydrobiologie 159:433-453.

Marzolf, E. R., P. J. Mulholland, and A. D. Steinman. 1994. Improvements to the diurnal upstream-downstream dissolved oxygen change technique for determining whole-stream metabolism in small streams. Canadian Journal of Fisheries and Aquatic Sciences 51:1591-1599.

Matthews, W. J., K. B. Gido, G. P. Garrett, F. P. Gelwick, J. G. SteWART, AND J. Schaefer. 2006. Modular experimental riffle-pool stream system. Transactions of the American Fisheries Society 135:1559-1566.

McCormick, P. V., And R. J. Stevenson. 1991. Mechanisms of benthic algal succession in lotic environments. Ecology 72:1835-1848.

McIntosh, A. R., AND C. R. Townsend. 1996. Interactions between fish, grazing invertebrates and algae in a New Zealand stream: a trophic cascade mediated by fishinduced changes to grazer behavior? Oecologia (Berlin) 108:174-181.

McIntyre, P. B., A. S. Flecker, M. J. Vanni, J. M. Hood, B. W. TAYLOR, and S. A. Thomas. 2008. Fish distributions and nutrient cycling in streams: can fish create biogeochemical hotspots? Ecology 89:2335-2346.

McIntyre, P. B., L. E. Jones, A. S. Flecker, And M. J. VAnni. 2007. Fish extinctions alter nutrient recycling in tropical freshwaters. Proceedings of the National Academy of Sciences of the United States of America 104:4461-4466.

Meyer, J. L., E. T. Schultz, and G. S. Helfman. 1983. Fish schools: an asset to corals. Science 220:1047-1049.

Mulholland, P. J., A. M. Helton, G. C. Poole, R. O. Hall, S. K. Hamilton, B. J. Peterson, J. L. Tank, L. R. Ashkenas, L. W. Cooper, C. N. Dahm, W. K. Dodds, S. E. G. Findlay, S. V. Gregory, N. B. Grimm, S. L. Johnson, W. H. McDowell, J. L. Meyer, H. M. Valett, J. R. Webster, C. P. Arango, J. J. Beaulieu, M. J. Bernot, A. J. Burgin, C. L. Crenshaw, L. T. Johnson, B. R. Niederlehner, J. M. O'Brien, J. D. Potter, R. W. Sheibley, D. J. Sobota, and S. M. ThomAs. 2008. Stream denitrification across biomes and its response to anthropogenic nitrate loading. Nature 452:202-205.

Murdock, J. N., AND W. K. DodDs. 2007. Linking benthic algal biomass to stream substratum topography. Journal of Phycology 43:449-460.

Murdock, J. N., K. B. Gido, W. K. Dodds, K. N. Bertrand, AND M. R. Whiles. 2010. Consumer return chronology alters recovery trajectory of stream ecosystem structure and function following drought. Ecology 91:1048-1062.

Murdock, J. N., D. R. Roelke, and F. P. Gelwick. 2004. Interactions between flow, periphyton, and nutrients in a heavily impacted urban stream: implications for stream restoration effectiveness. Ecological Engineering 22:197-207.

O'Brien, J. M., W. K. Dodds, K. C. Wilson, J. N. Murdock, AND J. EICHMILLER. 2007. The saturation of $\mathrm{N}$ cycling in Central Plains streams: N-15 experiments across a broad gradient of nitrate concentrations. Biogeochemistry 84: 31-49.
Peterson, C. G. 1996. Mechanisms of lotic microalgal colonization following space-clearing disturbances acting at different spatial scales. Oikos 77:417-435.

PofF, N. L., AND J. V. WARD. 1989. Implications of streamflow variability and predictability for lotic community structure: a regional analysis of streamflow patterns. Canadian Journal of Fisheries and Aquatic Sciences 46: 1805-1818.

POWER, M. E. 1990. Effects of fish in river food webs. Science 250:811-814.

Power, M. E., AND W. J. Matthews. 1983. Algae-grazing minnows (Campostoma anomalum), piscivorous bass (Micropterus spp.), and the distribution of attached algae in a small prairie-margin stream. Oecologia (Berlin) 60: 328-332.

Power, M. E., A. J. Stewart, And W. J. Matthews. 1988a. Grazer control of algae in an Ozark mountain stream: effects of short-term exclusion. Ecology 69:1894-1898.

Power, M. E., R. J. Stout, C. E. Cushing, P. P. Harper, F. R. Hauer, W. J. Matthews, P. B. Moyle, B. Statzner, and I. R. WAIS DE BADGEN. 1988b. Biotic and abiotic controls in river and stream communities. Journal of the North American Benthological Society 7:456-479.

Resh, V. H., A. B. Brown, A. P. Covich, M. E. Gurtz, H. W. Li, G. W. Minshall, S. R. Reice, A. L. Sheldon, J. B. Wallace, AND R. C. Wissmar. 1988. The role of disturbance in stream ecology. Journal of the North American Benthological Society 7:433-455.

RiER, S. T., AND R. J. STEVENSON. 2006. Response of periphytic algae to gradients in nitrogen and phosphorus in streamside mesocosms. Hydrobiologia 561:131-147.

Rosemond, A. D., P. J. Mulholland, And J. W. Elwood. 1993. Top-down and bottom-up control of stream periphyton: effects of nutrients and herbivores. Ecology 74:12641280.

Royall, R. M. 1997. Statistical evidence: a likelihood paradigm. Chapman and Hall, New York.

SARtory, D. P., and J. U. GrobbelaAr. 1984. Extraction of chlorophyll-a from fresh-water phytoplankton for spectrophotometric analysis. Hydrobiologia 114:177-187.

Stasiak, R. H. 2007. Southern Redbelly Dace (Phoxinus erythrogaster): a technical conservation assessment. Rocky Mountain Region, US Department of Agriculture Forest Service, Golden, Colorado. (Available from: http: / /www.fs.fed.us/r2/projects / scp/assessments / southernredbellydace.pdf)

Steinman, A. D. 1996. Effects of grazers on freshwater benthic algae. Pages 341-373 in R. J. Stevenson, M. L. Bothwell, and R. L. Lowe (editors). Algal ecology: freshwater benthic ecosystems. Academic Press, San Diego, California.

VANNI, M. J. 2002. Nutrient cycling by animals in freshwater ecosystems. Annual Review of Ecology and Systematics 33:341-370.

Vanni, M. J., A. M. Bowling, E. M. Dickman, R. S. Hale, K. A. Higgins, M. J. Horgan, L. B. Knoll, W. H. Renwick, And R. A. Stein. 2006. Nutrient cycling by fish supports relatively more primary production as lake productivity increases. Ecology 87:1696-1709. 
Welschmeyer, N. A. 1995. Fluorometric analysis of chlorophyll $\mathrm{a}$ in the presence of chlorophyll $\mathrm{b}$ and pheopigments. Limnology and Oceanography 39:1985-1992.

Worm, B., H. K. Lotze, H. Hillebrand, AND U. Sommer. 2002. Consumer versus resource control of species diversity and ecosystem functioning. Nature 417:848-851.

YounG, R. G., AND A. D. Huryn. 1998. Comment: further improvements to the diurnal upstream-downstream dissolved oxygen change technique for determining whole-stream metabolism in small streams.
Canadian Journal of Fisheries and Aquatic Sciences 55: 1784-1785.

Zimmer, K. D., B. R. Herwig, and L. M. Laurich. 2006. Nutrient excretion by fish in wetland ecosystems and its potential to support algal production. Limnology and Oceanography 51:197-207.

Received: 11 March 2010 Accepted: 1 December 2010 